\title{
Food aversion learning to eliminate cattle consumption of pine needles
}

\author{
JAMES A. PFISTER
}

Author is rangeland scientist, USDA-ARS Poisonous Plant Research Laboratory, 1150 E. 1400 N., Logan, Ut.84341. Email: jpfister@cc.usu.edu.

\begin{abstract}
Conditioned food aversions are a potentially useful tool to eliminate consumption of some toxic plants by livestock. This study examined consumption of pine needles (Pinus ponderosa Lawson) in South Dakota and Oregon by pregnant cattle. Averted cattle were conditioned to avoid green pine needles using a gastrointestinal emetic, lithium chloride; control (non-averted) animals were not treated. Averted and non-averted cattle were offered green pine needles during pen trials, and they were also grazed in pastures with abundant pine needles in 2 winter trials during 1997 and 1998. Averted cattle ate no green needles in pen trials in Oregon and South Dakota in either year; whereas, control cattle always ate some green needles during those tests. The 1997 South Dakota field trial was inconclusive: the averted cattle ate no needles and the control cattle ate almost no needles while grazing. In the 1998 Oregon field study, the averted cows began eating pine litter after $\mathbf{4}$ days in the pasture, and the aversion to green needles extinguished rapidly thereafter. In Oregon, controls ate more than $50 \%$ of their diet as pine needles, and particularly selected green needles from recently cut trees or branches. When the trial ended after 16 days, the controls and averted cattle were both eating about the same amount of green pine needles and dry needle litter even though they grazed in different pastures. Although averted to green needles, cattle did not appear to generalize the aversion from green needles to dry needle litter. Conditioning permanent aversions may require averting cattle to all forms of pine needles (i.e., green and dry) likely to be encountered in a pasture.
\end{abstract}

Key Words: diet selection, cattle diets, abortion, Pinus ponderosa

Conditioned food aversions are a potentially useful tool to eliminate consumption by livestock of some toxic plants, including tall larkspur (Delphinium barbeyi L. Huth., Lane et al. 1990, Ralphs 1997) and locoweed (Oxytropis sericea Nutt. in T. \& G., Ralphs et al. 1997). In aversion trials, the animal is typically exposed once to a novel food to overcome neophobia. After the initial exposure, a gastrointestinal emetic (usually lithium chloride, $\mathrm{LiCl}$ ) is given if the animal eats the target plant (Ralphs and Olsen 1990, Ralphs and Cheney 1993). The animal associates the resultant illness with the flavor of the plant and avoids eating the

All animal procedures were approved by the Utah State University Institutional Animal Care and Use Committee. I thank Kermit Price, Al Maciulis, and Rex Probst for assistance with various aspects of the study, and L.F. James for assistance in procuring cattle. Thanks also to Ned and Doris Westphal, Pringle, S. Dak., and Pete Rawlins, John Day, Ore. for allowing research on their ranches, and for their assistance in carrying out the study.

Manuscript accepted 17 Feb. 2000.

\section{Resumen}

La aversión condicionada a ciertos alimentos es una herramienta potencialmente útil para eliminar el consumo de algunas plantas tóxicas por el ganado. Este estudio examina el consumo de hojas de pino (Ponderosoa pine Lawson) por el vacas gestantes en las regiones de South Dakota y Oregon. Se condiciono ganado para evitar el consumo de hojas de pino utilizando emético gastrointestinal, cloruro de litio y se tuvieron animales control (sin tratamiento para inducir la aversión). A los animales con y sin aversión se les ofreció hojas verdes de pino en experimentos en corral y en dos experimentos conducidos en los inviemos de 1997 y 1998 estos animales apacentaron en potreros con abundancia de hojas de pino. En los experimentos de corral conducidos en Oregon y South Dakota el ganado con aversión no comió hojas verdes de pino mientras que el ganado sin aversión siempre comió algo de hojas verdes de pino. El estudio de campo de 1997 conducido en South Dakota no fue concluyente porque el ganado con aversión no comió hojas de pino y el ganado del grupo control casi no comió hojas de pino mientras apacentaba. En el estudio de Oregon de 1998, las vacas con aversión iniciaron a comer las hojas de pino del mantillo hasta después de $\mathbf{4}$ dias de estar en el potrero y la aversión por las hojas verdes de pino desapareció rapidamente después de iniciar el consumo. En Oregon mas del $50 \%$ de la dieta de las vacas control fue de hojas verdes de pino, particularmente seleccionadas de áboles o ramas recién cortadas. Al final del periodo de estudio (16 dias), tanto el ganado condicionado con aversión como el control comian casi la misma cantidad de hojas verdes y secas de pino presentes en el mantillo, esto sucedió a pesar que ambos grupos apacentaban en diferentes potreros. Aunque el ganado se condiciono para rechazar las hojas verdes de pino, parece que esta aversión no se generalizo en el ganado para rechazar las hojas secas del mantillo. El condicionar el ganado para evitar el consumo de hojas de pino puede requerir que los animales se condicionen para evitar el consumo de todas las formas (verdes y secas) de hojas de pino que se pueden encontrar en el potrero.

plant in future encounters (Provenza et al. 1990). Ralphs (1997) determined that aversions created to keep cattle from eating tall larkspur lasted for at least 3 years if averted cattle were not grazed with non-averted cohorts.

Conditioned aversions are unlikely to be an all-encompassing solution for most livestock producers with poisonous plant losses for a variety of reasons (Ralphs and Provenza 1999). The conditioning procedure is labor- and time-intensive; nausea induced by the emetic is somewhat stressful for the animal; the aversion works best if animals are naive to the target plant, and it is more 
difficult (but possible) to condition aversions to familiar plants; social facilitation will cause the aversion to extinguish if all herd animals are not averted; aversions to a specific plant may extinguish if averted animals eat closely related species. Solutions to poisonous plant problems will usually involve a number of other management options (e.g., tall larkspur; Pfister et al. 1999). Nonetheless, aversive conditioning may play an important preventative role in some ranching situations (Ralphs and Provenza 1999) and deserves careful consideration.

The purpose of this study was to determine if aversions could be conditioned in cattle to eliminate consumption of ponderosa pine (Pinus ponderosa Lawson) needles. Pine needles contain a diterpene acid that is a potent abortifacient compound (Gardner et al. 1994, 1996). Green and dry needles from the same source contain about the same levels of toxin (D. Gardner, unpublished data). When pregnant cattle consume pine needles (Pfister and Adams 1993, Pfister et al. 1998), abortions often occur and cows retain their fetal membranes (James et al. 1989). Calves may be born alive but often die shortly after birth. Pine needle-caused abortions and their sequelae of veterinary treatment and altered animal and range management costs the livestock industry millions of dollars annually (Lacey et al. 1988).

\section{Methods}

\section{Logan, Ut. Pen Trial}

Ten Hereford x Angus pregnant cows (469 $\pm 16 \mathrm{~kg}$ body weight) were randomly divided into 2 treatment groups $(n=5): 1)$ controls, and 2) those averted to pine needles. They were each fed $9 \mathrm{~kg} \mathrm{day}^{-1}$ of alfalfa hay. Green pine needles were collected in South Dakota and frozen until use. Beginning in early January, 1997, all cows were fasted overnight and at 0800 hours offered $100 \mathrm{~g}$ of freshly-harvested green pine needles for $15 \mathrm{~min}$ each day. Cattle were offered needles for a total of 8 days in Logan. Control cows ate an average of $90 \mathrm{~g} \mathrm{day}^{-1}$ of needles during the final 6 days of conditioning in Logan. Based on previous work (Pfister et al. 1998), we determined that cattle in the averted treatment must eat a minimum of $20 \mathrm{~g}$ (i.e., 2 to 4 bites) in order to be adequately exposed to the "flavor" of pine needles. Those that ate $>20 \mathrm{~g}$ were dosed with lithium chloride ( $\mathrm{LiCl})$ at $200 \mathrm{mg} \mathrm{kg}^{-1}$. The $\mathrm{LiCl}$ was mixed with tap water and given by stomach tube. Controls that ate needles were not dosed.
Three cows in the averted group ate $100 \mathrm{~g}$ of needles and were treated with $\mathrm{LiCl}$ on day 3 . The fourth averted-group cow ate sufficient pine needles and was dosed for the first time with $\mathrm{LiCl}$ on the fifth day of exposure, whereas the fifth cow in the averted group never ate any pine needles and was not dosed. After the initial $\mathrm{LiCl}$ dose, each averted animal ate no needles in 2 subsequent pen tests in Logan.

\section{South Dakota Field and Pen Trial}

The South Dakota pen and field tests were conducted on a commercial ranch near Pringle $\left(43^{\circ} 37^{\prime} 44^{\circ} \mathrm{N}\right.$ latitude, $103^{\circ}$ 41' 47' W longitude, $1,538 \mathrm{~m}$ elevation) using the 10 cows conditioned in Logan. On the second day at the ranch (16 January 1997) the cattle were fasted overnight, then penned individually and offered $100 \mathrm{~g}$ of freshly-harvested pine needles for $15 \mathrm{~min}$. Refusals were weighed to determine pine needle intake, and no $\mathrm{LiCl}$ was dosed. This test procedure was repeated periodically over the next 7 weeks. The next day the cattle were turned out to graze in 1 of 2 adjoining 3 -ha pastures with abundant pine tree populations in the area described by Pfister et al. (1998). Dormant grasses such as western wheatgrass (Agropyron smithii Rydb.), sideoats grama [Bouteloua curtipendula (Michx.) Torr.], and little bluestem [Schizachyrium scoparium (Michx.) Nash in Small] were abundant in the pastures. The averted and control cattle were not grazed in the same pasture for 14 days because we did not want consumption by control cows to influence the diet selection of cows in the averted group or vice versa (Ralphs and Olsen 1990, Ralphs 1997). The field study lasted 20 consecutive days, and the cattle were switched between pastures on days 5 and 10 . On day 14 the dividing fence between the pastures was taken down and the 2 groups of cattle grazed together thereafter. Cattle grazed each day during daylight hours and were penned at dusk each night; each evening they were fed $2.5 \mathrm{~kg} \mathrm{cow}^{-1}$ of grass hay. Repetitive 5-min bite counts were conducted for each cow during all active grazing periods by rotating systematically through both groups of cattle (Pfister et al. 1998). During bite counts, we recorded bites of pine needles (green and dry litter), dormant grasses and shrubs. The field portion ended on 5 February 1997; cattle remained at the ranch until 8 March 1997 when they were retested in the pen for the final time.

\section{Logan, Ut. Pen Trial}

Ten mature, pregnant beef Shorthorn cows $(640 \pm 46 \mathrm{~kg})$ were randomly divided into 2 treatment groups $(n=5): 1)$ averted to green pine needles, and 2) untreated controls. Ponderosa pine needles were collected fresh from western Idaho and kept frozen until use. One hour before pine needles were offered at 0900 hours, cattle were given a preload consisting of $0.75 \%$ of their body weight of a ground concentrate/hay mix $(60 \%$ alfalfa pellets [Medicago sativa]; 30\% corn [Zea mays]; $10 \%$ soybean meal [Glycine max]). A second equal offering was also given at 1500; total feed offered slightly exceeded maintenance. On days when no pine needles were offered, cattle were given alfalfa hay ad libitum. After an overnight fast, cows were individually offered $100 \mathrm{~g}$ of green pine needles for 15 min beginning on 1 January 1998 (day 1). Eight of 10 cows (4 controls and 4 in the to-be-averted group) ate all $100 \mathrm{~g}$ on the first day of exposure, but none were dosed with $\mathrm{LiCl}$. Intake by controls was highly variable on days 2 and 3 of exposure. During the remainder of the Logan pen trial from days 4 to 29 , the 5 control cows were each offered $300 \mathrm{~g}$, and they ate all the needles every day. On day 2 none of the cows in the to-be-averted group ate pine needles. On day 3 all 5 cows in the averted group ate $100 \mathrm{~g}$ of needles and were dosed with $\mathrm{LiCl}$ at 200 $\mathrm{mg} \mathrm{kg}^{-1}$ body weight immediately after eating needles. On day 6 , the averted cows were again offered green needles and no needles were eaten. On day 8 , the averted cows were retested, and 2 cows ate 50 to $100 \mathrm{~g}$ of needles and were again dosed with $\mathrm{LiCl}$. The averted cows were retested weekly on days 13,20 , and 27 , and all abstained until day 27, when the 3 averted cows that had not previously received a second $\mathrm{LiCl}$ dose ate 20 to $30 \mathrm{~g}$ of needles and were given a second dose of $\mathrm{LiCl}$.

An extinction trial is the elimination of an aversion by repeated presentations of a unconditioned stimulus (i.e., flavor of target food) without negative feedback (i.e., LiCl-induced nausea; Garcia 1989). Since each pen test was an extinction trial unless cows ate needles and were dosed with $\mathrm{LiCl}$, further pen studies in Logan were discontinued and all tests were conducted subsequently in a field study near John Day, Ore.

\section{Oregon Field and Pen Trial}

The Oregon trial was conducted on a commercial ranch near John Day, Ore. (44 $15^{\prime}$ '04" N latitude, $118^{\circ} 54^{\prime} 78^{\prime \prime} \mathrm{W}$ longitude, 1,267 $\mathrm{m}$ elevation) for 16 days 
(Jan. to Feb.) with the same cattle. Only 4 controls and 4 averted cattle were used as the other 2 cows were injured in an accident during transport and returned to Logan. An 18-ha pasture with numerous mature ponderosa pine trees was divided into 2 sections, and controls and averted cows grazed separately. The groups switched pastures every 4 days during the trial. Both green and dry needles were available; additional pine needles were provided by cutting down several trees within each pasture, and roughly equal amounts of freshly-cut branches from a nearby logging operation were deposited daily in each pasture. Each pasture had a 10 - to $15-\mathrm{cm}$ layer of dry needle litter under the intermittent tree canopy. Adequate amounts of dormant grasses (Festuca idahoensis Elmer, Poa spp., and Bromus spp.) provided virtually all of the available forage. Cattle were individually supplemented each evening with $1.8 \mathrm{~kg}$ of a ground mixture of corn $(30 \%)$, alfalfa pellets $(60 \%)$ and soybean meal $(10 \%)$. Bite counts were performed as detailed above, except that we also recorded whether pine needles were eaten from live trees or from trees or branches that had been cut down. All cows were individually penned and offered $100 \mathrm{~g}$ of freshly-harvested green needles for 15 min on days 4 and 11 of the field trial.

\section{Statistical analysis}

Both pen and field trials for 1997 and 1998 were analyzed using a repeated measures model with treatment (i.e., averted and control), individual animals nested within treatment (error a), day, day x treatment and residual error (b). Means were separated using the LSD procedure of SAS (1988) after a significant $(\mathrm{P}<0.05) \mathrm{F}$ test.

\section{Results and Discussion}

Averted cattle ate no pine needles in the pen or field trials in South Dakota, whereas non-averted control cattle ate $45 \mathrm{~g}$ (SE $=10$ ) of the $100 \mathrm{~g}$ offered in the various pen offerings. There was a day $x$ treatment interaction in the pen trial as the control cattle ate $10(\mathrm{SE}=8), 54(\mathrm{SE}=17), 42$ $(\mathrm{SE}=15)$ and $74(\mathrm{SE}=9) \mathrm{g}$ of needles on the 4 dates that they were tested. This increase in amount eaten over time suggests that cattle learned to accept needles. In further pen studies with cattle eating pine needles, repeated exposure to needles has increased acceptance over time (Pfister unpublished data). Other studies have reported similar observations for ani- mals response to novel foods (Launchbaugh et al. 1997). In the grazing portion in South Dakota, the control cattle ate only a few bites of pine needles during the 20-day trial, and they did not differ from the averted group (data not shown).

Even though the averted cattle ate no pine needles and controls ate needles in the pen trials, the South Dakota trial was inconclusive because control cattle ate almost no needles in the field test. In 2 previous trials at this location, cattle have either eaten a large amount of needles ( $\sim 50 \%$ of bites), or very few, depending on the weather and snow depth (Pfister et al. 1998). During the first week of this trial, ambient temperatures were typical (i.e., well below freezing), but then the weather warmed to above normal temperatures. Probably the most important factor in the lack of field consumption was the lack of accumulation of snow; rarely did more than 6 to $8 \mathrm{~cm}$ of snow accumulate at one time during the trial. Past results have shown that snow depth and accessibility of forage are major factors in consumption of pine needles by cattle (Pfister and Adams 1993, Pfister et al. 1998).

The cattle used in the Oregon study readily accepted pine needles on the first exposure after an overnight fast, perhaps because of previous experience with terpene-laden browse on a sagebrush (Artemisia spp.)-dominated range. These cattle were naive to pine needles, however, and a key factor in conditioning strong food aversions is relative novelty of the food (Domjan 1980). Aversions to novel foods are easier to condition than are aversions to familiar foods (Ralphs and Provenza 1999). It is possible, but unlikely, that the 1-day exposure with no $\mathrm{LiCl}$ treatment weakened the aversion. Exposure to a flavor with no paired illness has weakened aversions in rats through a "learned safety" mechanism (Kalat and Rozin 1973). Nonetheless, Burritt and Provenza (1996) found that a 1-day exposure does not weaken aversions in sheep, and that 7 days of experience are required to undermine the subsequent aversion. The averted cattle required 2 LiCl-pine needle pairings to condition a complete aversion in the pen, but that is common in conditioning aversions in cattle (Ralphs and Provenza 1999).

In the Oregon field trial, there was a treatment $\mathrm{x}$ day interaction $(\mathrm{P}<0.05)$ for amount of green needles (cut trees), pine litter, and grasses eaten (Fig. 1). The averted cattle took a few bites of green needles and litter on day 4 and, thereafter, increased the amount of litter eaten during the next 7 days. Near the end of the trial on day 13 , averted cattle began eating substantial amounts of green needles. The amount of grasses eaten diminished steadily during the trial in both groups of cows (Fig. 1) even though adequate grass was available in most of the pasture. On occasion the pastures were covered temporarily by snow, but generally temperatures were above normal, and it rained almost every day.

The averted cows ate no green pine needles in the first pen trial on day 4 , whereas controls averaged $75 \mathrm{~g} \mathrm{cow}^{-1}$. In the last pen test on day 11 , the averted cows again ate no green needles, and controls averaged 50 $\mathrm{g} \mathrm{cow}^{-1}$. We did not offer dry needles in any pen tests. One averted cow aborted her calf on day 13; the calf appeared to be fully developed but was born dead. This cow began eating pine litter on day 7 and ate mostly litter before aborting.

The aversion that had been conditioned to green needles was extinguished. Though untested, this may have been due to consumption of pine litter to which cattle were not averted. Initially, we observed that averted cattle avoided the dry needles even when eating grasses intermingled with substantial accumulations of dry needles. Indeed, the averted cattle actively spit out accidentally-ingested dry needles in those first few days. Nevertheless, after a few days, cattle began eating substantial quantities of dry needles, along with a few bites of green needles, and the aversion quickly extinguished. Two averted cows began eating needles first, followed by the remaining cows in the group. Social facilitation probably hastened the extinction of the aversion once some animals began to eat needles (Lane et al. 1990, Ralphs 1997). Aversions to locoweed and larkspur extinguish rapidly when grazing companions are eating the target plants (Ralphs and Provenza 1999).

Cattle were not averted to dry needles because I assumed they would generalize the aversion from the green needles to the dry needles. Apparently the flavor was sufficiently dissimilar that cattle were not deterred for more than a few days from consumption of dry needles. Olsen et al. (1989) reported that cattle averted to dry, ground larkspur did not generalize the aversion to fresh, green plant. In fact, Ralphs (unpublished) has recently found that cattle averted to 1 species of larkspur (D. barbeyi) using fresh plant do not generalize the aversion to another closely related larkspur species (D. occidentale) also offered as fresh material. It is difficult to speculate about similarity of flavors and how cattle might perceive dry and green 
(A) Control cows
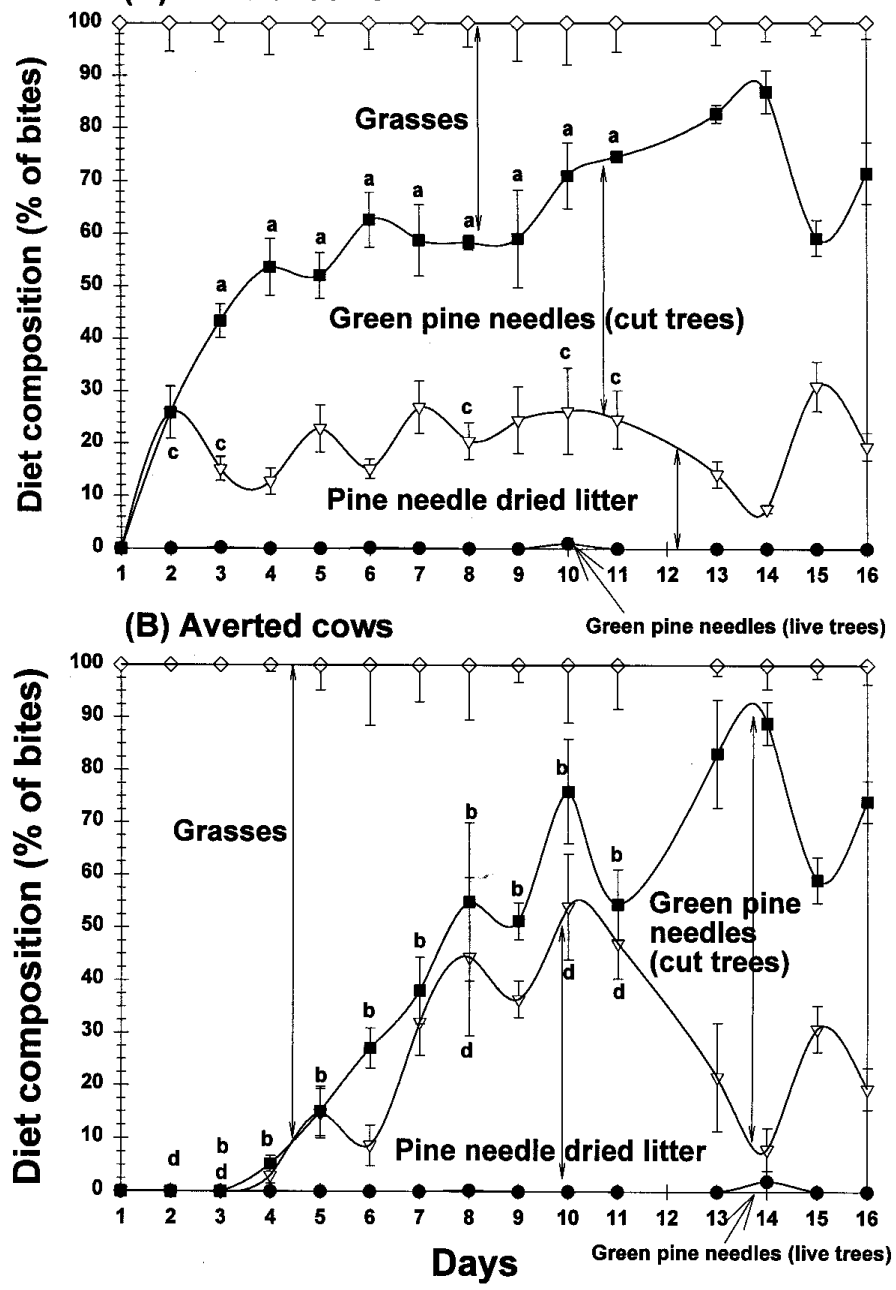

Fig. 1. Diet composition (cumulative percentage of bites with SE bars for each plant class) of control (i.e., untreated) and averted (i.e., conditioned to avoid pine needles) cattle near John Day, Ore. during late January and early February, 1998. Percentage composition is defined by the area between lines; for example for averted cows on day 1 grasses $=100 \%$ of bites, and on day 10 needles from cut trees $=22 \%$ of bites. For each particular day and plant class, different letters for controls and averted cattle indicate that diets differed $(P<$ 0.05; a,b for green pine needles from cut trees; $c, d$ for pine litter). Data for day 12 are missing.

needles. Intuitively, it seems that as overlap among flavors increases, generalization of an aversion will increase from one flavor to another. Losses of volatile compounds from green pine needles as they weather may result in flavors that are somewhat dissimilar. Further, weathered needles may initially be more acceptable to cattle than are fresh, green needles (Litvak and Monson 1998). Some toxic plants, like tall larkspur (Delphinium bar beyi), are not acceptable to cattle when immature (Pfister et al. 1997) but with changes in phenology become more acceptable, presumably because of flavor changes. These findings suggest that for aversions to be successfully created in grazing environments, livestock may need to be averted to every potential form of the target plant that will be encountered.

Averted cattle retained the aversion created in a pen when retested in the pen, even though the aversion was extinguished while grazing. This is similar to the findings of Ralphs and Olsen (1990) with regard to learning context. In their study, cattle that had extinguished an aversion to tall larkspur in the field retained the aversion when retested in a pen setting similar to that used in the original conditioning. Studies with rats (Lovibond et al. 1984, Bonardi et al. 1990) suggest that when a conditioned flavor (e.g., pine needles) is encountered in an unfamiliar context, the flavor is less capable of eliciting the same response (i.e., an aversion) than it does in a familiar context. Burritt and Provenza (1997) suggested that livestock should be conditioned to avoid toxic plants in the environment where they will forage to increase the strength of the aversion, but this may be impractical under many ranching situations.

Control cows in the Oregon study ate large amounts of needles even though ambient temperatures were above normal during most days on the study site (average maximum daily temperature $6.1^{\circ} \mathrm{C}$ ). This study cannot be realistically compared to other grazing studies that we have conducted on cattle eating pine needles (Pfister and Adams 1993, Pfister et al. 1998) because the control cows were conditioned to eat large quantities of needles in the pen, and this conditioning encouraged consumption of pine needles. Furthermore, cattle preferred the green needles from trees and branches that had been deliberately cut down over green needles from live trees. Anecdotal accounts suggest that cattle readily eat needles from slash piles, and this study confirmed that green, but drying, needles are readily accepted by cattle. Again, this may have been due to losses of volatile compounds from drying needles compared to needles on live trees (Litvak and Monson 1998 ). Thus, livestock producers with pine tree-infested pastures must exercise caution to keep pregnant cattle away from slash piles or fallen trees.

This study illustrates some of the potential problems with field application of aversive conditioning. First, the cattle used in Oregon had a history of eating browse, and this probably increased their propensity to eat pine needles. Second, the Oregon pastures were unfamiliar to all the cows, and the lack of familiarity may broadened diet selection patterns (Provenza 1997). Third, providing freshly-cut branches with green needles may have enhanced pine needle intake. Fourth, abundant dry needles mixed with grass may have provided the equivalent of multiple extinction trials as animals grazed in these patches underneath trees each day. Finally, it appears that cattle did not generalize the aversion from green to dry needles.

More work will be required to determine if aversive conditioning is a realistic option for livestock producers with toxicity problems from pine needle abortions. Cattle apparently must be averted to both dry and green needles in order to prevent consumption, and this reduces the practicality of the procedure. If pine litter is abundant, it may be difficult at times for cattle to avoid eating dry needles, thus 
weakening the aversive conditioning. Once cattle begin to eat pine litter, aversions to green needles appear to extinguish rapidly.

\section{Literature Cited}

Bonardi, C., R.C. Honey, and G. Hall. 1990. Context specificity of conditioning in flavor aversion learning: extinction and blocking tests. Anim. Learning Behav. 18:229-237.

Burritt, E.A. and F. D. Provenza. 1989. Food aversion learning: conditioning lambs to avoid a palatable shrub (Cercocarpus mon tanus). J. Anim. Sci. 67:650-653.

Burritt, E.A. and F.D. Provenza. 1996. Amount of experience and prior illness affect the acquisition and persistence of conditioned food aversions in lambs. Appl. Anim. Behav. Sci. 48:73-80.

Burritt, E.A. and F.D. Provenza. 1997. Effect of an unfamiliar location on the consumption of novel and familiar foods by sheep. Appl. Anim. Behav. Sci. 54:317-325.

Domjan, M. 1980. Ingestional aversion learning: unique and general processes, $\mathrm{p}$. 275-336. In: J.S. Rosenblat, R.A. Hinde, C. Beer, and M. Busnel (ed.), Advances in the study of behavior. Vol 11. Academic Press, New York, N.Y.

Garcia, J. 1989. Food for Tolman: cognition and cathexis in concert. p. 45-85. In: T. Archer and L. Nilsson (ed.), Aversion, avoidance and anxiety. Lawrence Eribaum Associates, Hillsdale, N.J.

Gardner, D.R., K.E. Panter, R.J. Molyneux, L.F. James, and B.L. Stegelmeier. 1996. Abortifacient activity in beef cattle of acetyland succinyl-isocuppressic acid from ponderosa pine. J. Agr. Food Chem. 44:3257-3261.

Gardner, D.R., R.J. Molyneux, L.F. James, K.E. Panter, and B.L. Stegelmeier. 1994. Ponderosa pine needle-induced abortion in beef cattle: identification of isocupressic acid as the principal active compound. J. Agr. Food Chem. 42:756-761.
James, L.F., R.E. Short, K.E. Panter, R.J. Molyneux, L.D. Stuart, and R.A. Bellows. 1989. Pine needle abortion in cattle: a review and report of 1973-1984 research. Cornell Vet. 79:39-52.

Kalat, J.W. and P. Rozin. 1973. "Learned safety" as a mechanism in long-delay taste aversion learning in rats. J. Comp. Physiol. Psychol. 83:198-207.

Lacey, J.R., L.F. James, and R.E. Short. 1988. Ponderosa pine: economic impact. $\mathrm{p}$. 95-106. In: L.F. James, M.H. Ralphs, and D.B. Nielsen (ed.), The ecology and economic impact of poisonous plants on livestock production. Westview Press, Boulder, Colo.

Lane, M.A., M.H. Ralphs, J.D. Olsen, F.D. Provenza, and J.A. Pfister. 1990. Conditioned taste aversion: potential for reducing cattle losses to larkspur. J. Range Manage. 43:127-131.

Launchbaugh, K.L., F.D. Provenza, and M.J. Werkmeister. 1997. Overcoming food neophobia in domestic ruminants through addition of a familiar flavor and repeated exposure to novel foods. Appl. Anim. Behav. Sci. 54:327-334

Litvak, M.E. and R.K. Monson. 1998. Patterns of induced and constitutive monoterpene production in conifer needles in relation to insect herbivory. Oecologica 114:531-540.

Lovibond, P.F., G.C. Preston, and N.J. Mackintosh. 1984. Context specificity of conditioning and latent inhibition. J. Exper. Psych.: Anim. Behav. Proc. 10:360-375.

Olsen, J.D., M.H. Ralphs, and M.A. Lane. 1989. Aversion to eating poisonous larkspur plants induced in cattle by intraruminal infusion with lithium chloride. J. Anim. Sci. 67:1980-1985.

Pfister, J.A. and D.C. Adams. 1993. Factors influencing pine needle consumption by grazing cattle during winter. J. Range Manage. 46:394-398.

Pfister, J.A., K.E. Panter, and D.R. Gardner. 1998. Pine needle consumption by cattle during winter in South Dakota. J. Range Manage. 51:551-556.
Pfister, J.A., M.H. Ralphs, G.D. Manners, D.R. Gardner, K.W. Price, and L.F. James. 1997. Early season grazing by cattle of tall larkspur- (Delphinium spp.) infested rangeland. J. Range Manage. 50:391-398.

Pfister, J.A., D.R. Gardner, K.E. Panter, G.D. Manners, M.H. Ralphs, B.L. Stegelmeier, and T.K. Schoch. 1999. Larkspur (Delphinium spp.) poisoning in livestock. J. Natural Toxins 8:81-94.

Provenza, F.D. 1997. Feeding behavior of herbivores in response to plant toxicants. p. 231-242. In: J.P. D’Mello (ed.), Handbook of plant and fungal toxicants. CRC Press, Boca Raton, Fla.

Provenza, F.D., E.A. Burritt, T.P. Clausen, J.P. Bryant, P.B. Reichardt, and R.A. Distel. 1990. Conditioned flavor aversion: a mechanism for goats to avoid condensed tannins in blackbrush. Amer. Nat. 136:810-828.

Ralphs, M.H. 1997. Persistence of aversions to larkspur in naive and native cattle. J. Range Manage. 50:367-370.

Ralphs, M.H. and C.D. Cheney. 1993. Influence of cattle age, lithium chloride dose level, and food type in retention of food aversions. J. Anim. Sci. 71:373-379.

Ralphs, M.H. and J.D. Olsen. 1990. Adverse influence of social facilitation and learning context in training cattle to avoid eating larkspur. J. Anim. Sci. 68:1944-1952.

Ralphs, M.H., and F.D. Provenza. 1999. Conditioned food aversion: principles and practices, with special reference to social facilitation. Proc. Nutr. Soc. 58:1-8.

Ralphs, M.H., D. Graham, M.L. Galyean, and L.F. James. 1997. Creating aversions to locoweed in naive and familiar cattle. J. Range Manage. 50:361-366.

SAS. 1988. SAS User's Guide SAS/STAT ${ }^{\circledR}$ (Release 6.03). SAS Inst. Inc., Cary, N.C. 